\title{
Design of unbraced multi-storey steel frames under combined loading
}

\section{ANDERSON \& M. A. ISLAM}

Professor F. W. Williams, University of Wales Institute of Science and Technology

The following points could make the Authors' method even more attractive.

44. The calculation of the deteriorated critical load in $\$ 29$ could be replaced by the simpler procedure of checking that $\lambda_{1}$ lies below this critical load, by using $\$ \$ 10-12$ of reference 29 with $K_{\mathrm{bi}}$ given by tangential stiffnesses, as in $\$ 29$, instead of by equation (5) of reference 29 .

45. The sway deflexions of $\$ 27$ could then be found by the method of $\$ 3-6$ of reference 29 , with $K_{\text {bi }}$ given by secant stiffnesses, as in $\$ 27$, instead of by equation (5) of reference 29 . This change and that in $\$ 44$ are both ideally suited to programming, and coding economies result because both changes involve equations (3), (4) and (6)-(13) of reference 29.

46. The methods of reference 29 optionally include the simple representation of cladding permitted in the Merchant-Rankine approach. Thus the changes proposed enable cladding to be included in all the Authors' sway deflexion and critical load steps. As their other steps are unaltered by this simple representation of cladding, the changes in $\$ \$ 44$ and 45 enable the Authors' method to make an allowance for cladding.

\section{Dr Anderson and Dr Islam}

The method Professor Williams proposes will enable a unified approach to be made to the calculation of both sway deflexion and the deteriorated critical load. Also, by including cladding stiffness, a less conservative approach can be made to design.

\section{Reference}

29. WiLliams F. W. Consistent, exact, wind and stability calculations for substitute sway frames with cladding. Proc. Instn Civ. Engrs, Part 2, 1979, 67, June, 355-367; 1979, 67, Sept., 889.

Paper published: Proc. Instn Civ Engrs, Part 2, 1980, 69, Mar., 49-62. 